considered by the editors of the Society for General Microbiology's symposium volume Symbiotic Associations (1963) to "disguise a fundamentally parasitic relationship". Held at the Royal Institution in London, the meeting included presentations of elegant experimental work on the nature of certain symbiotic associations and stimulated critical scientific work that developed exponentially over the next two decades, mainly through the energy of David Smith's group in Oxford. I would have welcomed more analysis of the results of such investigations, of experimental work on isolated partners, and the insights from synthesis experiments and ultrastructural studies.

For lichens, new evidence of 'controlled parasitism' at the cellular level has prompted the question whether mutualism should be defined at the individual cell level or in terms of increased fitness of the partners at the social level. Within lichen associations in which neither partner occurs in a free-living form, the symbiosis cannot be other than mutually beneficial at the social level. As lichens are such a key element in the development of the original concept of 'symbiosis', I would have enjoyed commentary on this topical scaling controversy.

Overall, the book is a delightful historical complement to the available texts describing symbiotic associations and a scholarly overview of the conceptual aspects of the subject. It will be enjoyed both by symbiologists and by those interested in the history of biological thought.

David L. Hawksworth is at the International Mycological Institute, Bakeham Lane, Egham, Surrey TW10 9TY, UK.

\title{
Juicy beetle and other stories
}

\section{S. J. Simpson}

Bugs in the System: Insects and their Impact on Human Affairs. By May R. Berenbaum. Addison-Wesley: 1995. Pp. 337. \$25 (hbk); £19.95 (pbk).

WE entomologists are a frustrated lot. It is blindingly obvious that insects are both beautiful and amazing, so why doesn't everybody else realize this? Granted, the aesthetic appeal of many insects is perhaps a tad difficult to convey to those poor souls without an entomocentric view, but insects are amazing. And how do we entomologists try to convert our long-suffering colleagues, friends and, in fact, anyone else unfortunate enough to enquire politely what we do for a living? Why, we tell them amazing things about insects. May Berenbaum has provided us with the ultimate source of incredible entomological facts. As I read the book I folded back the corner of each page containing an extraordinary piece of entomologia. My copy will not close now. There is enough here to keep entomological evangelists in stories for generations to come.

Did you know that the production of 1 kilogram of honey involves 10 million visits to individual flowers and bees flying the equivalent of 10 times around the Earth? Or that the extraordinary abundance of chamber pots excavated from the Aztec capital was due to human urine being used as a mordant for cochineal dye? Or that the larvae of some flea species attach to the anus of the adult and imbibe their faeces? Or that there is a club in Washington, DC, that specializes

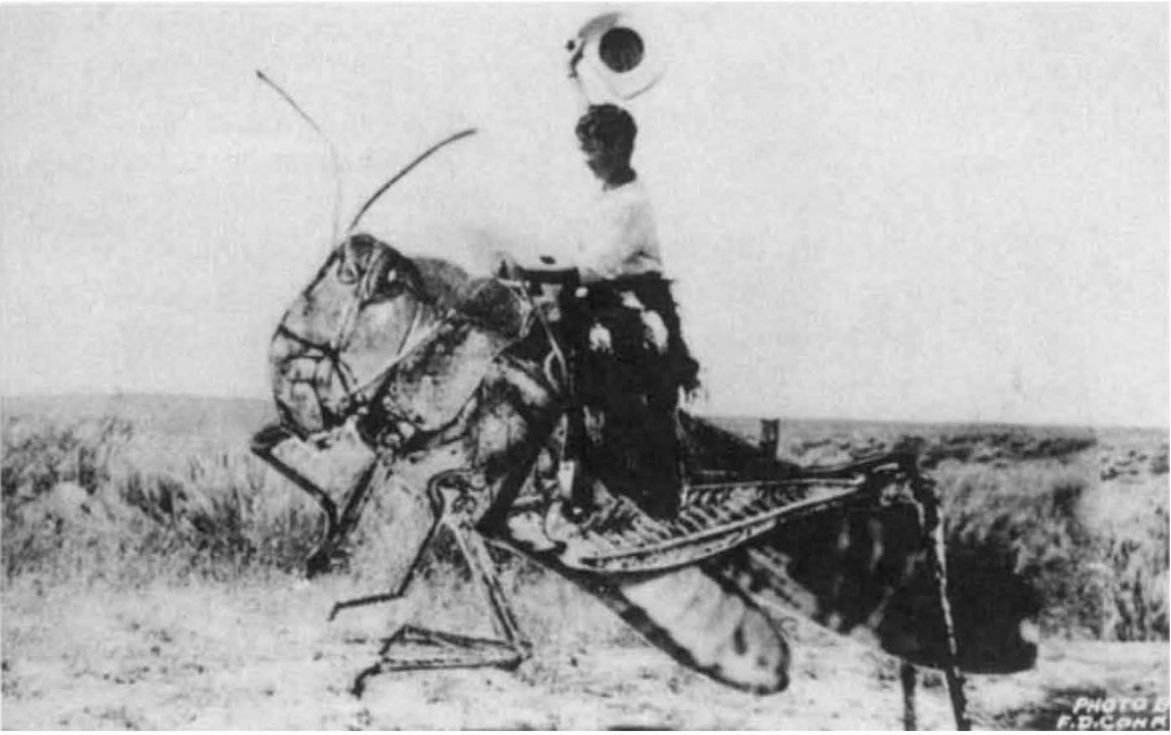

Leap of imagination - a novelty postcard from the turn of the century. in organically produced mealworm wontons and cricket peanut-butter cups? Or that an elephant-dung pat in East Africa was removed in 2 hours by 16,000 dung beetles? Do you know what canthariasis or autothysis are? Or that... ?

Berenbaum has provided a comprehensive account of the ways in which insects have influenced human affairs, along with salient features of insect behaviour, physiology, social organization and life history. Aspects as diverse as the importance of insects in art, agriculture, food, fly fishing, forensic medicine, mythology, warfare, social structure and even human evolution are covered. Implicating insects in the evolution of the opposable thumb (for social grooming) may be over-entomocentric, but emphasizing their impact on other aspects of human society and biology clearly is not.

For example, the Second World War was the first ever war in which lousetransmitted typhus did not kill more people than the number who died in battle. In 1812 Napoleon embarked on his attempt to conquer Russia with an army of 600,000 men. A year later only 3,000 remained, most of the rest having died of typhus. Thanks to its, demographic effects, the Black Death contributed greatly to the decline of the manorial system in Europe. The automobile was encouraged as a nonpolluting alternative to horse-drawn vehicles, which were associated with dung-breeding, disease-transmitting fly populations.

This fascinating compendium is written in an appropriately light-hearted style. There are plenty of bad puns (when referring to the extreme competition among carrion-feeding insects, for example, the author says: "It's a dead-dog-eatdead-dog world out there") and, inevitably, in the interests of a balanced coverage, there is a lot of sex and defecation, so the book will appeal to all biologists. Whether, with its mass of detail, it will hold the attention of lay readers, particularly those with a delicate constitution, is perhaps doubtful. But then again, they will receive the information second-hand from us entomologists on aeroplanes and buses and at dinner parties all over the globe - whether or not they want to hear it.

Finally, I must just mention the case in 1970 when a hotel owner was sued by a guest "who, while attempting to get rid of a cockroach which crawled up her thighs, got her legs entangled in a bedspread and stumbled and fell over". Canthariasis? That is the infestation of the rectum by dung-feeding beetles. And autothysis? Explosive defecation in which the abdomen is blown off.

S. J. Simpson is at the University Museum, University of Oxford, Parks Road, Oxford OX1 3PW, UK. 